\title{
Schema Theory and Categorization of Student and Teacher Metaphors
}

\author{
Ebrahim Khodadady \\ Ferdowsi University of Mashhad, International Branch, Mashhad, Iran \\ Email: ekhodadady@um.ac.ir \\ Mostafa Morady Moghaddam \\ Young Researchers Club, Mashhad Branch, Islamic Azad University, Mashhad, Iran \\ Hoda Kanan Azar \\ Ferdowsi University of Mashhad, International Branch, Mashhad, Iran
}

\begin{abstract}
This study explored whether the metaphors written by 504 Iranian learners of English and 140 English teachers behaved like semantic features of the schemata they likened themselves to. The 239 student and 249 teacher metaphors elicited from the participants were submitted to four raters who assigned them to 13 conceptual categories established by Saban, Kocbeker, and Saban (2007). The statistical analysis of data showed that the categories behave as collective knowledge because there is no significant difference in the frequency of student metaphors written by both students and teachers who view students as passive recipients of knowledge, developing organisms and absolute compliants. Students and teachers, however, differ significantly as regards teacher categories. While the highest percentage of students metaphorised their teachers as facilitators/scaffolders, the teachers assigned a counselor's role to themselves, indicating that metaphors are sensitive to social positions. Since the categories are pretty stable over age, proficiency level, years and fields of study as well as experience, they reflect the ever-evolving nature of schema in the variety of metaphors with which the categories are depicted and thus reflect the reality of language learning and teaching in Iran.
\end{abstract}

Index Terms - Schema theory, semantic features, categories, individual and collective knowledge

\section{INTRODUCTION}

Burke (1945) defined metaphor as "a device for seeing something in terms of something else" (p. 503). However, Lakoff and Johnson (2005) extended it to acquiring the meaning of something according to another and Yazıc1 (2010) gave it a synonymous function by demarcating it as using a word instead of another. In spite of being different in perspective, the explication of metaphor by these scholars shares the key terms "something" and "something else" referred to as Topic and Vehicle by Richards (1936) and Perrine (1971), respectively, for the first time (see Cameron, 1999).

In addition to the Topic and Vehicle of metaphors, Saban, Kocbeker, and Saban (2007) [henceforth SKS07] added the third element, i.e., Ground, to study 1142 prospective teachers' conceptions of teaching and learning. When filling out the sheet containing the prompt, "A teacher is like ... because ..." a female participant, for example, wrote, "A teacher is like a gardener because s/he deals with different kinds of students like a gardener deals with different kinds of plants." The teacher, gardener and the reason or nature of relationship form the Topic, Vehicle and Ground of the metaphor, respectively.

The very addition of Ground as the third element of conceptual analysis helped SKS07 "break down each metaphor into analyzable parts, looking for salient features/ images, common elements, and similarities among the various metaphors" (p. 127). Their analysis of the responses given to the prompt resulted in establishing 10 main conceptual categories for teachers as shown in Table 1. When the metaphor Book is, for example, used as a vehicle by a metaphoriser to describe the metaphorised Teacher as a topic, his/her Student is regarded as a passive recipient of knowledge whose task is just absorbing whatever there is in the Book. 
TABLE 1

SKS07'S SIXTY EXEMPLAR METAPHORS FOR TEN CONCEPTUAL CATEGORIES OF TEACHERS

\begin{tabular}{|l|l|l|l|}
\hline$\#$ & Topic (Teacher) & Vehicle (Metaphor) & Ground (Student) \\
\hline 1 & Knowledge provider & $\begin{array}{l}\text { Book, candle, computer, flower, fountain, jug, light, pen, rain, } \\
\text { shopkeeper, spring, sun, television, tree, writer, poet }\end{array}$ & Passive recipient of knowledge \\
\hline 2 & Molder/craftsperson & $\begin{array}{l}\text { Architect, baker, carpenter, constructor, cook, honeybee, } \\
\text { ironworker, jeweler, mill, miner, painter, potter, sculptor, } \\
\text { tailor, technician, weaver, }\end{array}$ & Raw material \\
\hline 3 & Curer/repairer & Doctor, mechanic, medicine & Defective individual \\
\hline 4 & Superior authoritative figure & Brain, locomotive, shepherd, ship captain & Absolute compliant \\
\hline 5 & Change agent & Fashion designer, scriptwriter & Object of change \\
\hline 6 & Entertainer & Actors, actresses, stand-up comedian & Conscious observant \\
\hline 7 & Counselor & Companion, psychologist, friend, mother, father & Developing organism \\
\hline 8 & Nurturer/cultivator & Chameleon, farmer, gardener, soil, & Constructor of knowledge \\
\hline 9 & Facilitator/scaffolder & $\begin{array}{l}\text { Bridge, compass, flashlight, ladders, lighthouse, north star, } \\
\text { road map, taxi driver, torch, traffic signs, }\end{array}$ & $\begin{array}{l}\text { Active participant in a } \\
\text { community of practice }\end{array}$ \\
\hline 10 & Cooperative/democratic leader & Coach, conductor, tour guide, & \\
\hline
\end{tabular}

The study of metaphors in terms of their topic, vehicle and ground is quite dehumanized and decontextualised because the terms topic, vehicle and ground have no reference to the metaphorisers as the sources of metaphors. For this very reason Yob (2003) believed that metaphors are employed when humans try to understand and address "something [italic added] esoteric, abstract, novel, or highly speculative. As a general rule, the more abstract or speculative it is, the greater the variety of metaphors needed to grapple with it" (p. 134). Yob's view stands in sharp contrast to Phillips (1996) who believed that a metaphor such as a gardener may help understand teachers but it may also act as a block to look for more promising perspectives.

This study takes a totally different approach towards studying metaphors by treating them as semantic features which reflect the ever evolving nature of a given schema such as a student and a teacher. They reflect language users' personal attitudes and feelings towards as well as experiences with the schema metaphorised. The schema teacher, for example, has many semantic features which relate to and distinguish it from other similar schemata such as students and pupils in a specific place at a given time.

Figure 1 presents some of the semantic features speakers have in their minds when they utter the schemata student and teacher. As can be seen, the first feature shows that teachers and students are human by nature. However, some language learners may not capitalize on this feature in their teachers and focus instead on their being resourceful and thus liken them to books and dictionaries. Others though may pay more attention to their teachers' caring role and liken them to fathers and wives. These lived and experienced semantic features of schemata do in fact distinguish them from words in that the definition of teachers and students as words in dictionaries lack many semantic features interlocutors usually associate with the schemata teachers and students in their every day verbal interactions.

\begin{tabular}{|l|l|l|l|l|l|l|l|}
\hline Schemata & Human & Caring & Receiving & Initiating & Resourceful & Being paid & Being sought \\
\hline Teacher & + & + & - & + & + & + & + \\
\hline Students & + & \multicolumn{1}{l}{ FIGURE 1. SEMANTIC FEATURES OF TEACHERS AND STUDENTS AS SCHEMATA } \\
\hline
\end{tabular}

The term schema was first used by Khodadady $(1997,1999)$ and Khodadady and Herriman (2000) to demarcate a word or phrase produced by an addresser to represent a real entity such as a teacher in combination with other words/phrases comprising a text. Khodadady, Pishghadam, and Fakhar (2010), for example, classified schemata comprising certain units of three textbooks taught at an intermediate level of language proficiency into three domains, i.e., semantic, syntactic and parasyntactic, to study the relationship among reading comprehension ability, grammar and vocabulary knowledge. As did Khodadady, Shirmohammadi, and Talebi, (2011) to study brainstorming and its effect on critical thinking and speaking skills. While semantic schemata such as nouns are many in type but few in their frequency, the syntactic schemata such as pronouns are few in type but many in frequency. Parasyntactic schemata such as names may be many in both type and frequency but always play a syntactic role in language comprehension and production.

The first evidence supporting the treatment of metaphors as semantic features of schemata comes from their belonging to one specific domain, i.e., semantic. As can be seen in Table 1, all teacher metaphors employed by SKS07's participants are nouns and belong only to semantic domain in that they are open or many in type. Secondly, they are hierarchical in the sense that many metaphors can be subsumed under a single category. And finally, they are personal and reflect metaphorisers' individualistic experiences with the schema they metaphorise and thus differentiate them from words as abstract units of language.

If metaphors behave like the semantic features of a given schema, as it is claimed in this study, they must represent not only collective knowledge but also individual experiences of the metaphorisers with the schema under investigation. In other words, as the collective knowledge of a given schema, the categories into which the metaphors of that schema are subsumed should not be significantly different for given groups of metaphorisers, i.e., students and teachers in this 
study. As indicators of individual experiences, the categories of metaphors must, however, differ significantly not only from a given group, i.e., teachers, to another group, i.e., students, but also from metaphor to metaphor because their status or social positions provide them with different experiences. This study is, therefore, designed to test these assumptions.

\section{Methodology}

\section{A. Participants}

Three groups of people took part in this study, i.e., English learners and teachers in private institutes and four raters majoring in Teaching English as a Foreign Language (TEFL) at Ferdowsi University of Mashhad.

English Language Learners

Two hundred seventy three (54.2\%) female and $231(45.8 \%)$ male learners of English took part voluntarily in the project. One hundred ninety six (38.9\%), 139 (27.6\%), 85 (16.9\%) and 84 (16.7\%) were studying at Rayehe Danesh, Iran language Institutes, Meraj Andishe and Shokuh, respectively. Their age ranged from 10 to 50 (mean = 18.62, SD = 5.34) and they all spoke Persian as their mother language. Table 2 shows the frequency (F), percent (P) and cumulative percent $(\mathrm{CP})$ of the number of years $(\mathrm{Y})$ the 504 participants had spent learning English. As can be seen it ranged from one to 18 years $($ mean $=3.71, \mathrm{SD}=1.97)$.

TABLE 2

THE NUMBER OF YEARS SPENT ON STUDYING ENGLISH (Y) AND THEIR FREQUENCY (F), PERCENT (P) AND CUMULATIVE PERCENT (CP)

\begin{tabular}{|l|l|l|l|l|l|l|l|l|l|l|l|l|}
\hline $\mathbf{Y}$ & $\mathbf{F}$ & $\mathbf{P}$ & $\mathbf{C P}$ & $\mathbf{Y}$ & $\mathbf{F}$ & $\mathbf{P}$ & $\mathbf{C P}$ & $\mathbf{Y}$ & $\mathbf{F}$ & $\mathbf{P}$ & $\mathbf{C P}$ \\
\hline $\mathbf{1}$ & 25 & 5.0 & 5.0 & $\mathbf{6}$ & 21 & 4.2 & 91.7 & $\mathbf{1 1}$ & 1 & .2 & 99.6 \\
\hline $\mathbf{2}$ & 123 & 24.4 & 29.4 & $\mathbf{7}$ & 13 & 2.6 & 94.2 & $\mathbf{1 2}$ & 1 & .2 & 99.8 \\
\hline $\mathbf{3}$ & 138 & 27.4 & 56.7 & $\mathbf{8}$ & 17 & 3.4 & 97.6 & $\mathbf{1 8}$ & 1 & .2 & 100.0 \\
\hline $\mathbf{4}$ & 72 & 14.3 & 71.0 & $\mathbf{9}$ & 4 & .8 & 98.4 & Total & 504 & 100.0 & & \\
\hline $\mathbf{5}$ & 83 & 16.5 & 87.5 & $\mathbf{1 0}$ & 5 & 1.0 & 99.4 & & & & \\
\hline
\end{tabular}

\section{English Language Teachers}

In addition to 504 learners of English, 140 teachers, 78 female (55.7\%) and 62 male (44.3), took part in the study voluntarily. Their age ranged from 18 to 50 (mean $=26.7, \mathrm{SD}=5.47$ ). They were either studying for or held a degree in English Language and Literature $(n=47, \%=33.6)$, Teaching English as a Foreign Language $(n=44, \%=31.4)$, English Translation $(\mathrm{n}=35, \%=25)$. (Fourteen teachers $(10 \%)$ did not, however, specify their field of study.)

Their experience in teaching English ranged from one to 22 years (mean $=3.9, \mathrm{SD}=3.35$ ). They were teaching at Bayan $(\mathrm{n}=24, \%=17 \%)$, Iran Language Institute $(\mathrm{n}=32, \%=22.9 \%)$, Meraj Andishe $(\mathrm{n}=28, \%=20 \%)$, Rayehe Danesh $(\mathrm{n}=28, \%=20 \%)$, and Shokuh $(\mathrm{n}=28, \%=20 \%)$ institutes when the research was conducted. They all spoke Persian as their mother language.

\section{Four Raters}

The present male researchers categorized the metaphors in consultation with each other as rater 1 . The metaphors along with the rater 1's categories taken from the topic and ground columns of Table 1 as well as SKS07's examples were then sent separately to two female and one male raters who were doing their graduate studies at Ferdowsi University of Mashhad. They were asked to decide independently which category each metaphor belonged to. The raters had all taught general English at various private and public language schools for more than five years.

\section{B. Instrument}

The instrument used in the study was a questionnaire consisting of two parts: While the biodata section differed for the students and teachers, the prompts were the same. In the biodata section the learners were asked to specify their gender, age, years of studying English and the name of the institute they were attending when they took part in the project whereas the teachers were to specify their field of study and years of teaching English along with their gender and age. The second part consisted of two prompts for both the learners and teachers. First, the question, "What is your idea about a student?" was asked. Then the incomplete sentence, "A student is like ..." was given to be completed. Similarly, for the second prompt the question "What is your idea about a teacher?" was raised first and the incomplete sentence, "A teacher is like ..." was given immediately to be completed.

\section{Procedure}

The researchers attended the institutes in person and invited both the teachers and learners to participate in the study. Upon their agreement the questionnaire was administered on the spot and in the case of the teachers having no extra time, another session was set to have their students fill it out. The researchers then went back to the same teacher on the specified date and distributed the questionnaire either in their teachers' presence or alone.

After 240 and 245 metaphors written for English students and teachers, respectively, were specified, they were alphabetically ordered and the two male researchers of this study established their categories by frequently consulting and discussing Table 1 and the examples provided by SKS07. The researchers' ratings were specified as Rater 1 and then the metaphors and rated categories along with SK0S's examples were sent to a female graduate of TEFL to 
categorize the teacher and student metaphors separately as Rater 2. She was also asked to explain why she disagreed with Rater 1 whenever she categorized a given metaphor differently.

A comparison of Rater 1 and 2's categories showed that they agreed neither on student nor on teacher metaphors at the required level, i.e., .90 or higher (Miles \& Huberman, 1994). Out of 240 student metaphors they agreed on 182, i.e., $182 / 240=.76$. Similarly, the agreement coefficient for teacher metaphors was .80, i.e., 198/245. The metaphor Cigarette, for example, was categorized as Defective Individual by Rater 1. Rater 2, however, categorized it as Facilitator/scaffolder because

At first glance, I see no association between cigarette and teacher. Cigarette is usually associated with destruction, fatality and disease. But viewing from another perspective, while not justified and acceptable for me [italics are added], some smokers believe it is soothing and it facilitates their control over anger or stress or even regulates their temper!

In spite of being not justified and acceptable for Rater 2, she had, nonetheless, categorized Cigarette as Facilitator/scaffolder. In order to reach the acceptable level of agreement, Rater 1's categories along with SKS07's examples were, therefore, sent to male Rater 3. Since most of Rater 3's categorization was the same as Rater 1's, they were treated as cases of agreement and Rater 2's categories were discarded wherever it disagreed with a given metaphor assigned to the same category by both Rater 1 and 3. In some cases, Rater 3's categories, however, agreed with Rater 2's though he had no access to her ratings. In such cases, Rater 1's category was discarded. Rater 1 had, for example, categorized Autumn as Facilitator/scaffolder but both Rater 2 and 3 had categorized it as Change Agent. The adopting of this procedure increased the agreement to the acceptable level of .96 (231/240) for student metaphors and .97 $(238 / 245)$ for teachers.

Since all the elicited metaphors were going to be analyzed in this study, the few metaphors upon which the three raters disagreed were changed into a three-choice item test and sent to another female Rater along with SKS07's examples. She was told that the three alternatives presented for each metaphor were categorized by three different raters. She was asked to read the examples very carefully and choose the alternative which best fit her own experiences with English students as well teachers as shown in the directions and example given below:

Dear Rater:

Would you please read the attached file containing example sentences for metaphor categories very carefully and then based on your personal experiences with both English students and teachers, specify which alternative provides the best description for a teacher likened to an object such as a Book. A colleague of yours chose C, Knowledge provider, as the best alternative.

Example: $\quad$ A teacher likened to a Book is like a ...
A Change agent
B Facilitator/scaffolder
C Knowledge provider *

The selections made by rater four were adopted as the category upon which 100 percent agreements were reached and thus no metaphor was discarded from the study. This approach resulted in establishing more categories for both student and teacher metaphors as will be discussed shortly.

\section{Data Analysis}

All the metaphors produced by both English teachers and students were arranged alphabetically and assigned to categories established by SKS07 and extended further in this study. While SKS07 identified only 10 categories for teachers, for example, the four raters of this study added Absolute compliant, Active participant, Change object and Defective individual to the list, too. Similarly, the students were assigned to 13 categories on the basis of the examples SKS07 had given in their study. The reliability of these categories was then determined by subjecting them to inter rater analyses to reach 100 percent agreement by employing four raters. And finally, the categories were analyzed statistically by employing Crosstabs and Chi-Square test to explore the following six null hypotheses.

H1There is no significant difference in the student categories metaphorised by students of varying age, gender, and years of study

$\mathrm{H} 2$ There is no significant difference in the teacher categories metaphorised by students of varying age, gender, years of study

H3There is no significant difference in the student categories metaphorised by teachers of varying field of study, age, gender, and years of teaching.

H4There is no significant difference in the teachers categories metaphorised by teachers of varying fields of study, age, gender, and years of teaching.

H5 There is no significant difference in the student categories metaphorised by teachers and students themselves

H6 There is no significant difference in the teacher categories metaphorised by students and teachers themselves

\section{RESUlTS AND DisCUSSION}

Table 3 presents the number of metaphors written by students and teachers. As it can be seen, both students and teachers wrote 239 and 245 metaphors for students and teachers, respectively. (Appendices A and B provide all the metaphors along with their categories and frequencies.) The number of teacher metaphors, i.e., 167 (68.2\%), written by the students is higher than those they wrote for themselves, i.e., $141(59 \%)$. However, the number of student metaphors 
written by both students and teachers, i.e., 77 (32.2\%) was higher than that of teacher metaphors, i.e., 53 (21.6\%), indicating that they shared more common views regarding students metaphors.

TABLE 3

THE NUMBER OF METAPHORS WRITTEN BY STUDENTS AND TEACHERS

\begin{tabular}{|l|l|l|l|l|l|}
\hline \multirow{2}{*}{ Metaphoriser } & \multirow{2}{*}{$\mathbf{N}$} & Student Metaphor & \multicolumn{2}{l|}{ Teacher Metaphor } \\
\cline { 3 - 6 } & & Frequency & Percent & Frequency & Percent \\
\hline Students (Ss) & 504 & 141 & 59.0 & 167 & 68.2 \\
\hline Teachers (Ts) & 140 & 21 & 8.8 & 25 & 10.2 \\
\hline Both Ss and Ts & 644 & 77 & 32.2 & 53 & 21.6 \\
\hline Total & & 239 & 100.0 & 245 & 100.0 \\
\hline
\end{tabular}

Table 4 presents the 13 student categories metaphorised by students of varying age, gender, and years of study. As can be seen, the frequency of categories is of almost the same number for teens and adults, females and males and freshman and senior learners of English. Most of them, for example, consider themselves as passive recipients of knowledge, developing organisms and absolute compliants. The Chi-Square analysis of these frequencies thus confirmed the first hypothesis that there is no significant difference in the student categories metaphorised by students of varying age, gender, and years of study, implying that the schema of student, for example, invokes the image of certain objects in the minds of students of all ages, gender and proficiency level to reflect their being as empty as bags, banks, and baskets to be filled by teachers.

TABLE 4

THE STUDENT CATEGORIES METAPHORISED BY STUDENTS

\begin{tabular}{|c|c|c|c|c|c|c|}
\hline \multirow[b]{2}{*}{ Metaphor Category } & \multicolumn{2}{|c|}{ Age Group } & \multicolumn{2}{|c|}{ Gender } & \multicolumn{2}{|l|}{ Years of Study } \\
\hline & 10 to 18 & $\begin{array}{l}19 \text { and } \\
\text { higher }\end{array}$ & $\mathbf{F}$ & $\mathbf{M}$ & $\begin{array}{l}\text { Freshman and } \\
\text { sophomore }\end{array}$ & Junior and senior \\
\hline Passive recipient & 84 & 86 & 90 & 80 & 90 & 80 \\
\hline Developing organism & 47 & 46 & 51 & 42 & 58 & 35 \\
\hline Absolute compliant & 40 & 30 & 43 & 27 & 44 & 26 \\
\hline Active participant & 24 & 15 & 21 & 18 & 26 & 13 \\
\hline Defective individual & 18 & 11 & 13 & 16 & 20 & 9 \\
\hline Raw material & 18 & 21 & 19 & 20 & 19 & 20 \\
\hline Constructor of knowledge & 15 & 10 & 16 & 9 & 13 & 12 \\
\hline Molder/craftsperson & 5 & 4 & 5 & 4 & 3 & 6 \\
\hline Significant other & 5 & 6 & 6 & 5 & 3 & 8 \\
\hline Conscious observant & 4 & 7 & 6 & 5 & 7 & 4 \\
\hline Superior authoritative figure & 2 & 4 & 2 & 4 & 1 & 5 \\
\hline Nurturer/cultivator & 0 & 1 & 0 & 1 & 1 & 0 \\
\hline \multirow[t]{2}{*}{ Object of change } & 0 & 1 & 1 & 0 & 1 & 0 \\
\hline & 262 & 242 & 273 & 231 & 286 & 218 \\
\hline
\end{tabular}

Khodadady (1997) suggested that a given word such as a student which is produced by a writer in a given context such as the first prompt of this study, i.e., a student is like ..., be treated as a schema because it embodies a large number of closely related concepts, i.e., metaphors, which relate it to the writer's personal experiences with the same schema in other real contexts where the metaphors are employed non-metaphorically. Viewing the metaphorised student as a schema, for example, explains why 46 different metaphors have been written by the students themselves to show their own personal experiences, and consequent identification, with the metaphors such as bags and baskets as they have experienced committing vocabulary to their memories as real containers at home. (Appendix A provides a complete list of these metaphors.) While the word student exists only in dictionaries and can never embody metaphors elicited in this study as parts of their static definition, the schema student does accomplish the task in the variety of metaphors produced in this study.

Table 5 presents the teacher categories metaphorised by students of varying age, gender, and years of study. As can be seen, most learners view their teachers as facilitators, knowledge providers and counselors. The Chi-Square analysis run on the frequency of all teacher categories confirmed the second hypothesis that there is no significant difference in the teacher categories metaphorised by students of varying age, gender, years of study. These results indicate that similar to the schema of student, the schema of teacher evolves steadily over age, gender and years of study and thus provides further support for Khodadady and Elahi's (2012) argument that schemata are collective knowledge acquired personally through different experiences. 
TABLE 5

THE TEACHER CATEGORIES METAPHORISED BY STUDENTS

\begin{tabular}{|l|l|l|l|l|l|l|}
\hline \multirow{2}{*}{ Metaphor Category } & \multicolumn{2}{|l|}{ Age Group } & \multicolumn{2}{l|}{ Gear of Study } \\
\cline { 2 - 7 } & $\mathbf{1 0}$ to $\mathbf{1 8}$ & $\begin{array}{l}\mathbf{1 9} \text { and } \\
\text { higher }\end{array}$ & $\mathbf{F}$ & $\mathbf{M}$ & \multicolumn{2}{l|}{$\begin{array}{l}\text { Freshman and } \\
\text { sophomore }\end{array}$} \\
\hline Facilitator/scaffolder & 61 & 76 & 75 & 62 & 81 & \\
\hline Knowledge provider & 60 & 57 & 67 & 50 & 63 & 56 \\
\hline Counselor & 44 & 37 & 42 & 39 & 49 & 54 \\
\hline Nurturer/cultivator & 26 & 21 & 19 & 28 & 26 & 32 \\
\hline Cooperative/democratic leader & 18 & 16 & 19 & 15 & 18 & 21 \\
\hline Superior authoritative figure & 15 & 8 & 13 & 10 & 17 & 16 \\
\hline Entertainer & 13 & 7 & 12 & 8 & 11 & 6 \\
\hline Curer/repairer & 10 & 3 & 6 & 7 & 10 & 9 \\
\hline Molder/craftsperson & 9 & 13 & 15 & 7 & 7 & 3 \\
\hline Absolute compliant & 3 & 0 & 0 & 3 & 3 \\
\hline Change agent & 3 & 0 & 2 & 1 & 0 & 15 \\
\hline Active participant & 0 & 1 & 1 & 0 & 0 \\
\hline Defective individual & 0 & 3 & 2 & 1 & 1 \\
\hline Total & 262 & 242 & 273 & 231 & 286 \\
\hline
\end{tabular}

The teacher schema, for example, activates the mental images of objects such as chairs, guns, windows, beds, buses, cameras, carpets, and heaters in the minds of students and they employ these images consciously as metaphors to depict their English teachers' role in their language learning. The personal experiences of the highest number of student participants in this study with facilitating humans such as workers and detectives, locations such as classrooms and boulevards, and objects such as erasers and heaters have provided them with metaphors to liken their teachers to. Similarly, the second largest percentage views their teachers as trees and mountains because as real plants and locations, they have provided the students with their required types of fruit and landscape, respectively, as their teachers have provided them with English knowledge in a similar manner.

The findings presented in Table 5 also indicate that the learners assign their evolving schemata into more comprehensive categories to show their collective knowledge of metaphorised schemata such as students and teachers. The metaphors themselves, however, show how the students view the collective knowledge of the same schema personally. This very unique feature of schema explains why 68 metaphors have been written by the students alone to reveal the facilitative role of their teachers. One of them, for example, has employed the Persian slang metaphor Anorak, i.e., a person with a strong interest in niche subjects, to depict her teacher's facilitative role in helping her acquire proficiency in English as a niche language.

Table 6 presents the 12 student categories metaphorised by teachers of varying age, field of study, gender and teaching years. As can be seen, the frequency of categories is almost the same in each category indicating that the majority of young and adult, female and male, less and more experienced teachers look at their students as passive recipients. The Chi-square analysis of frequencies did not show any significant difference among categories and thus confirmed the third hypothesis that there is no significant difference in the student categories metaphorised by teachers of varying field of study, age, gender, and years of teaching.

TABLE 6

THE STUDENT CATEGORIES METAPHORISED BY TEACHERS

\begin{tabular}{|c|c|c|c|c|c|c|c|c|c|c|}
\hline \multirow[b]{2}{*}{ Categories } & \multicolumn{2}{|c|}{ Age Group } & \multicolumn{4}{|c|}{ Field of study* } & \multicolumn{2}{|c|}{ Gender } & \multicolumn{2}{|c|}{ Teaching years } \\
\hline & 18 to 25 & $\begin{array}{l}26 \text { and } \\
\text { older }\end{array}$ & 1 & 2 & 3 & 4 & $\mathbf{F}$ & $\mathbf{M}$ & 1 to 3.5 & 4 and more \\
\hline Passive recipient & 23 & 18 & 17 & 12 & 3 & 9 & 22 & 19 & 24 & 17 \\
\hline Developing organism & 11 & 16 & 11 & 7 & 4 & 5 & 11 & 16 & 21 & 6 \\
\hline Absolute compliant & 9 & 12 & 5 & 5 & 3 & 8 & 12 & 9 & 13 & 8 \\
\hline Raw material & 5 & 6 & 2 & 5 & 2 & 2 & 4 & 7 & 8 & 3 \\
\hline Active participant & 4 & 6 & 3 & 4 & 2 & 1 & 7 & 3 & 4 & 6 \\
\hline Conscious observant & 4 & 1 & 1 & 2 & 0 & 2 & 5 & 0 & 4 & 1 \\
\hline Constructor of knowledge & 4 & 6 & 3 & 5 & 0 & 2 & 7 & 3 & 7 & 3 \\
\hline Defective individual & 3 & 5 & 3 & 2 & 0 & 3 & 5 & 3 & 3 & 5 \\
\hline Knowledge provider & 1 & 0 & 0 & 0 & 0 & 1 & 0 & 1 & 1 & 0 \\
\hline Molder/craftsperson & 1 & 1 & 0 & 1 & 0 & 1 & 1 & 1 & 1 & 1 \\
\hline Significant other & 1 & 2 & 1 & 1 & 0 & 1 & 3 & 0 & 2 & 1 \\
\hline Superior authoritative figure & 0 & 1 & 1 & 0 & 0 & 0 & 1 & 0 & 1 & 0 \\
\hline Total & 66 & 74 & 47 & 44 & 14 & 35 & 78 & 62 & 89 & 51 \\
\hline
\end{tabular}

* (1) LITERATURE, (2) METHODOLOGY, (3) OTHER, AND (4) TRANSLATION

Table 7 presents the 11 teacher categories metaphorised by teachers of varying age, field of study, gender and teaching years. As can be seen, the frequency is similar in each category for the teacher participants. The majority of young and adult, female and male and less and more experienced teachers with degrees in four different fields look at themselves as counselors, facilitators, cooperative leaders and nurturers. The Chi-square analysis of frequencies did not 
show any significant difference among the categories and thus confirmed the fourth hypothesis that there is no significant difference in the teachers categories metaphorised by teachers of varying fields of study, age, gender, and years of teaching.

TABLE 7

THE TEACHER CATEGORIES METAPHORISED BY TEACHERS

\begin{tabular}{|c|c|c|c|c|c|c|c|c|c|c|}
\hline \multirow[b]{2}{*}{ Categories } & \multicolumn{2}{|c|}{ Age Group } & \multicolumn{4}{|c|}{ Field of Study* } & \multicolumn{2}{|c|}{ Sex } & \multicolumn{2}{|c|}{ Teaching years } \\
\hline & 18 to 25 & $\begin{array}{l}26 \text { and } \\
\text { older }\end{array}$ & 1 & 2 & 3 & 4 & $\mathbf{F}$ & $\mathbf{M}$ & 1 to 2.5 & $\begin{array}{l}3.5 \text { and } \\
\text { more }\end{array}$ \\
\hline Counselor & 12 & 17 & 13 & 8 & 3 & 5 & 14 & 15 & 9 & 14 \\
\hline Facilitator/scaffolder & 12 & 11 & 4 & 8 & 3 & 8 & 15 & 8 & 11 & 5 \\
\hline Cooperative/democratic leader & 10 & 10 & 7 & 7 & 2 & 4 & 11 & 9 & 13 & 4 \\
\hline Nurturer/cultivator & 10 & 9 & 9 & 2 & 2 & 6 & 6 & 13 & 4 & 9 \\
\hline Knowledge provider & 8 & 7 & 2 & 6 & 2 & 5 & 10 & 5 & 6 & 7 \\
\hline Molder/craftsperson & 7 & 10 & 5 & 7 & 1 & 4 & 9 & 8 & 3 & 8 \\
\hline Superior authoritative figure & 4 & 2 & 3 & 3 & 0 & 0 & 4 & 2 & 2 & 2 \\
\hline Absolute compliant & 1 & 0 & 1 & 0 & 0 & 0 & 0 & 1 & 1 & 0 \\
\hline Change agent & 1 & 0 & 0 & 0 & 1 & 0 & 0 & 1 & 1 & 0 \\
\hline Entertainer & 1 & 6 & 1 & 3 & 0 & 3 & 7 & 0 & 1 & 4 \\
\hline Defective individual & 0 & 2 & 2 & 0 & 0 & 0 & 2 & 0 & 0 & 2 \\
\hline & 66 & 74 & 47 & 44 & 14 & 35 & 78 & 62 & 51 & 55 \\
\hline
\end{tabular}

* (1) LITERATURE, (2) METHODOLOGY, (3) OTHER, AND (4) TRANSLATION

Table 8 presents the 14 categories into which the metaphors written by students and teachers have been assigned by the four raters. As can be seen, there is almost a perfect agreement regarding what categories the majority of students fall from both students and teachers' perspective. Since the frequency of metaphors written by both groups is almost the same, the Chi-square test thus confirmed the fifth hypothesis postulating the lack of significant difference as regards what both teachers and students liken the students' role in learning English.

TABLE 8

STUDENT CATEGORIES METAPHORISED BY TEACHERS AND STUDENTS THEMSELVES

\begin{tabular}{|c|c|c|c|c|c|}
\hline \multirow{2}{*}{ Metaphor Categories } & \multicolumn{2}{|c|}{ Metaphoriser } & \multirow{2}{*}{ Total } & \multirow{2}{*}{ Percent } & \multirow{2}{*}{$\begin{array}{l}\text { Cumulative } \\
\text { percent }\end{array}$} \\
\hline & Student & Teacher & & & \\
\hline Passive recipient & 170 & 41 & 211 & 32.8 & 32.8 \\
\hline Developing organism & 93 & 27 & 120 & 18.6 & 51.4 \\
\hline Absolute compliant & 70 & 21 & 91 & 14.1 & 65.5 \\
\hline Raw material & 39 & 11 & 50 & 7.8 & 73.3 \\
\hline Active participant & 39 & 10 & 49 & 7.6 & 80.9 \\
\hline Defective individual & 29 & 8 & 37 & 5.7 & 86.6 \\
\hline Constructor of knowledge & 25 & 10 & 35 & 5.4 & 92.1 \\
\hline Conscious observant & 11 & 5 & 16 & 2.5 & 94.6 \\
\hline Significant other & 11 & 3 & 14 & 2.2 & 96.7 \\
\hline Molder/craftsperson & 9 & 2 & 11 & 1.7 & 98.4 \\
\hline Superior authoritative figure & 6 & 1 & 7 & 1.1 & 99.5 \\
\hline Nurturer/cultivator & 1 & 0 & 1 & .2 & 99.8 \\
\hline Object of change & 1 & 0 & 1 & .2 & 99.7 \\
\hline \multirow[t]{2}{*}{ Knowledge provider } & 0 & 1 & 1 & .2 & 100.0 \\
\hline & 504 & 140 & 644 & & \\
\hline
\end{tabular}

The results presented in Table 8 support the argument made in this study that metaphors provide the most factual and experiential data through which a given society's collective as well as personal understanding of its key members such as students and teachers can be assessed. They do, for example, indicate that almost $75 \%$ of students have no choice but play the role of passive recipients, developing organisms, absolute compliants and raw materials in a context where the language they learn has no communicative role to play. In other words, the inability of Iranian learners to employ their English for real purposes as molders, for example, do, leave them with no other choice. However, $7.6 \%$ of these learners do manage to learn English as active participants.

Table 9 presents the teacher categories metaphorised by students and teachers themselves. As can be seen, while the highest percentage of students $(27.2 \%)$ metaphorised their teachers as facilitators/scaffolders, the highest percentage of teachers $(20.7 \%)$ assigned a counselor's role to themselves. Similarly, the second highest percentage of students and teachers see teachers differently, i.e., knowledge providers (23.2\%) and facilitators/ scaffolders (16.4\%), respectively. The Chi-square analysis of category frequencies showed that they were significantly different, i.e. $\chi^{2}=40.351$, df $=12$, $\mathrm{p}<.0001$, and thus disconfirmed the sixth hypothesis that there is no significant difference in the teacher categories metaphorised by students and teachers themselves. 
TABLE 9

TEACHER CATEGORIES METAPHORISED BY STUDENTS AND TEACHERS THEMSELVES

\begin{tabular}{|c|c|c|c|c|c|c|c|}
\hline \multirow{2}{*}{ Metaphor category } & \multicolumn{3}{|c|}{ Student } & \multicolumn{3}{|c|}{ Teacher } & \multirow{2}{*}{$\begin{array}{l}\text { Total } \\
\text { F }\end{array}$} \\
\hline & $\mathbf{F}$ & $\mathbf{P}$ & $\mathbf{C P}$ & $\mathbf{F}$ & $\mathbf{P}$ & $\mathbf{C P}$ & \\
\hline Facilitator/scaffolder & 137 & 27.2 & 27.2 & 23 & 16.4 & 37.1 & 160 \\
\hline Knowledge provider & 117 & 23.2 & 50.4 & 15 & 10.7 & 87.9 & 132 \\
\hline Counselor & 81 & 16.1 & 66.5 & 29 & 20.7 & 20.7 & 110 \\
\hline Nurturer/cultivator & 47 & 9.3 & 75.8 & 19 & 13.6 & 65.0 & 66 \\
\hline Cooperative/democratic leader & 34 & 6.7 & 82.5 & 20 & 14.3 & 51.4 & 54 \\
\hline Superior authoritative figure & 23 & 4.6 & 87.1 & 6 & 4.3 & 97.1 & 29 \\
\hline Molder/craftsperson & 22 & 4.4 & 91.5 & 17 & 12.1 & 77.1 & 39 \\
\hline Entertainer & 20 & 4.0 & 95.4 & 7 & 5.0 & 92.9 & 27 \\
\hline Curer/repairer & 13 & 2.6 & 98.0 & 0 & - & - & 13 \\
\hline Absolute compliant & 3 & 6 & 98.6 & 1 & .7 & 99.3 & 4 \\
\hline Change agent & 3 & .6 & 99.2 & 1 & .7 & 100.0 & 4 \\
\hline Defective individual & 3 & .6 & 99.8 & 2 & 1.4 & 98.6 & 5 \\
\hline \multirow[t]{2}{*}{ Active participant } & 1 & .2 & 100.0 & 0 & - & - & 1 \\
\hline & 504 & 100 & & 140 & 100 & & 644 \\
\hline
\end{tabular}

\section{CONCLUSION}

This study was designed to find out whether the metaphors language learners and teachers are likened to behave like semantic features through which the metaphorised schemata, i.e., students and teachers, were viewed under the conditions determining English learning in Iran in 2011. It was found that the majority of both students and teachers view learners as passive recipients, developing organisms and absolute complaints. In other words students and teachers of all ages, gender, years of study/teaching and the field of study regard English learners as passive and developing recipients of knowledge who comply with the rules set by their society. It was argued that the categories assigned are natural within a foreign language context because the very lack of authentic interlocutors, i.e., English speakers, with whom they can actively communicate and thus become active participants makes learning the language receptive, i.e., passive, rather than productive, i.e., active.

Students and teachers, however, have significantly different views as regards teachers' roles. While the highest percentage of English learners assign a facilitating role to their teachers by likening them to objects such as chairs and windows, the highest percentage of teachers give themselves a counseling role and liken themselves to friends and hearers. Students also assign the two roles of curers and active participants to teachers while the teachers do not see themselves in those roles, indicating that there is a discrepancy as regards what educational roles English teachers play in Iran. It is, therefore, suggested a more in-depth schema-based analysis of teachers be conducted by having the teachers articulate what they liken themselves and their students to and why. Their explicit metaphors and explanations must show why the second highest percentage of students views teachers as knowledge providers whereas teachers assign a facilitator's role to themselves.

And finally, treating metaphors as semantic features of the metaphorised schemata such as students and teachers reflect their pragmatic definitions within the variables of place and time and accomplish the task many authorities in language education strive to capture theoretically. In communicative Language Teaching, for example, several roles are assigned to teachers, e.g., needs analysts, counselors and group process managers (Richards \& Rodger, 2001). The metaphors elicited in this study, however, show that what some teaching experts theorise about teachers' roles hardly reflects the reality in Iranian language classes and results in a significant difference in what teachers think they are and what their students liken them to.

\section{APPENDIX A}

239 student metaphors produced by students and teachers (MV (Metaphoriser values): 1=students, 2=teachers, $3=$ students and teachers, CV (Category values): 1=Absolute compliant, 2 =Active participant, 3 =Conscious observant, 4=Constructor of knowledge, 5=Defective individual, 6=Developing organism, 7=Facilitator/scaffolder, 8=Knowledge provider, $9=$ Molder/craftsperson, 10=Nurturer/cultivator, 11=Object of change, 12=Passive recipient, 13=Raw material, 14=Significant other, $15=$ Superior authoritative figure

ST: Student token or the number of times the metaphor is produced by students; TT: Teacher token or the number of times the metaphor is produced by teachers) 


\begin{tabular}{|c|c|c|c|c|c|c|c|c|c|c|c|c|c|}
\hline No & MV & Student Metaphor & $\mathrm{CV}$ & ST & TT & Sum & No & MV & Student Metaphor & CV & ST & TT & Sum \\
\hline 1 & 1 & Belt & 1 & 1 & 0 & 1 & 35 & 3 & Waiter & 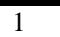 & $\overline{1}$ & $\overline{0}$ & $\overline{1}$ \\
\hline 2 & 1 & Bench & 1 & 1 & 0 & 1 & 36 & 2 & Watch & 1 & 1 & 1 & 2 \\
\hline 3 & 1 & Bicycle & 1 & 1 & 0 & 1 & 37 & 2 & Wave & 1 & 2 & 1 & 3 \\
\hline 4 & 1 & Bus & 1 & 1 & 0 & 1 & 38 & 3 & Wheel & 1 & 0 & 1 & 1 \\
\hline 5 & 1 & Carpet & 1 & 1 & 0 & 1 & 39 & 1 & Yoyo & 1 & 2 & 0 & 2 \\
\hline 6 & 3 & Employer & 1 & 1 & 0 & 1 & 40 & 3 & Ball & 2 & 5 & 2 & 7 \\
\hline 7 & 1 & Fish & 1 & 3 & 0 & 3 & 41 & 2 & Adventurer & 2 & 0 & 1 & 1 \\
\hline 8 & 1 & Floor & 1 & 3 & 0 & 3 & 42 & 1 & Artist & 2 & 4 & 0 & 4 \\
\hline 9 & 1 & Handkerchief & 1 & 3 & 1 & 4 & 43 & 1 & Athlete & 2 & 1 & 0 & 1 \\
\hline 10 & 1 & Hen & 1 & 2 & 1 & 3 & 44 & 1 & Buyer & 2 & 1 & 0 & 1 \\
\hline 11 & 3 & Horse & 1 & 3 & 0 & 3 & 45 & 1 & Dancer & 2 & 1 & 0 & 1 \\
\hline 12 & 1 & Key & 1 & 4 & 1 & 5 & 46 & 1 & Doctor & 2 & 2 & 1 & 3 \\
\hline 13 & 1 & Keyboard & 1 & 1 & 0 & 1 & 47 & 3 & Driver & 2 & 1 & 0 & 1 \\
\hline 14 & 1 & Kite & 1 & 1 & 0 & 1 & 48 & 3 & Explorer & 2 & 0 & 1 & 1 \\
\hline 15 & 1 & Knife & 1 & 1 & 0 & 1 & 49 & 1 & Fan & 2 & 1 & 0 & 1 \\
\hline 16 & 1 & Machine & 1 & 1 & 0 & 1 & 50 & 3 & Heart & 2 & 1 & 0 & 1 \\
\hline 17 & 1 & Marker & 1 & 4 & 0 & 4 & 51 & 1 & Leader & 2 & 1 & 0 & 1 \\
\hline 18 & 1 & Media player & 1 & 0 & 1 & 1 & 52 & 1 & Lover & 2 & 3 & 3 & 6 \\
\hline 19 & 3 & Money & 1 & 6 & 2 & 8 & 53 & 3 & Perfume & 2 & 1 & 1 & 2 \\
\hline 20 & 3 & Plane & 1 & 1 & 1 & 2 & 54 & 3 & Processor & 2 & 2 & 0 & 2 \\
\hline 21 & 1 & Police & 1 & 0 & 1 & 1 & 55 & 3 & Risk taker & 2 & 5 & 3 & 8 \\
\hline 22 & 1 & Poster & 1 & 1 & 0 & 1 & 56 & 1 & Speaker & 2 & 1 & 0 & 1 \\
\hline 23 & 1 & \begin{tabular}{|l} 
Programme \\
\end{tabular} & 1 & 2 & 0 & 1 & 57 & 3 & Swimmer & 2 & 1 & 1 & 2 \\
\hline 24 & 1 & Road & 1 & 2 & 1 & 3 & 58 & 3 & Taxi driver & 2 & 3 & 2 & 5 \\
\hline 25 & 3 & Robot & 1 & 4 & 0 & 4 & 59 & 3 & Teacher & 2 & 1 & 0 & 1 \\
\hline 26 & 3 & Ruler & 1 & 2 & 0 & 2 & 60 & 1 & Teeth & 2 & 1 & 1 & 2 \\
\hline 27 & 1 & Scissors & 1 & 1 & 0 & 1 & 61 & 1 & Tour & 2 & 1 & 0 & 1 \\
\hline 28 & 2 & Sheep & 1 & 2 & 1 & 3 & 62 & 1 & Tourist & 2 & 1 & 0 & 1 \\
\hline 29 & 3 & Software & 1 & 2 & 0 & 2 & 63 & 3 & Clown & 3 & 1 & 1 & 2 \\
\hline 30 & 3 & Soldier & 1 & 1 & 2 & 3 & 64 & 1 & Eagle & 3 & 1 & 0 & 1 \\
\hline 31 & 2 & Tire & 1 & 5 & 0 & 5 & 65 & 1 & Eye & 3 & 2 & 1 & 3 \\
\hline 32 & 1 & Train & 1 & 2 & 0 & 2 & 66 & 1 & Owl & 3 & 1 & 1 & 2 \\
\hline 33 & 2 & Training dog & 1 & 1 & 0 & 1 & 67 & 3 & Player & 3 & 3 & 1 & 4 \\
\hline 34 & 1 & Typewriter & 1 & 1 & 0 & 1 & 68 & 1 & Singer & 3 & 5 & 1 & 6 \\
\hline
\end{tabular}

\section{Appendix A (Continued)}

\begin{tabular}{|c|c|c|c|c|c|c|c|c|c|c|c|c|c|}
\hline No & MV & Student Metaphor & CV & ST & TT & Sum & No & MV & Student Metaphor & CV & ST & TT & Sum \\
\hline 69 & 1 & Wrestler & 3 & 7 & 0 & 7 & 104 & 1 & Virus & 5 & 1 & 0 & 1 \\
\hline 70 & 1 & Ant & 4 & 1 & 0 & 1 & 105 & 1 & Volcano & 5 & 1 & 0 & 1 \\
\hline 71 & 2 & Bee & 4 & 0 & 1 & 1 & 106 & 3 & Baby & 6 & 24 & 7 & 31 \\
\hline 72 & 2 & Computer program & 4 & 14 & 2 & 16 & 107 & 3 & Bird & 6 & 6 & 3 & 9 \\
\hline 73 & 3 & Discoverer & 4 & 1 & 0 & 1 & 108 & 1 & Butterfly & 6 & 2 & 0 & 2 \\
\hline 74 & 1 & Door & 4 & 2 & 0 & 2 & 109 & 1 & Cat & 6 & 1 & 0 & 1 \\
\hline 75 & 1 & Dream & 4 & 1 & 1 & 2 & 110 & 3 & Child & 6 & 12 & 5 & 17 \\
\hline 76 & 1 & Engine & 4 & 2 & 1 & 3 & 111 & 3 & Cloud & 6 & 4 & 1 & 5 \\
\hline 77 & 1 & Fire & 4 & 1 & 0 & 1 & 112 & 1 & Dog & 6 & 1 & 0 & 1 \\
\hline 78 & 1 & Glasses & 4 & 1 & 0 & 1 & 113 & 1 & Donkey & 6 & 3 & 0 & 3 \\
\hline 79 & 1 & Mountain climber & 4 & 4 & 0 & 4 & 114 & 1 & Drop of water & 6 & 6 & 1 & 7 \\
\hline 80 & 3 & Operator & 4 & 0 & 1 & 1 & 115 & 1 & Elephant & 6 & 1 & 0 & 1 \\
\hline 81 & 1 & Producer & 4 & 2 & 1 & 3 & 116 & 3 & Field & 6 & 2 & 0 & 2 \\
\hline 82 & 3 & Researcher & 4 & 2 & 0 & 2 & 117 & 1 & Finger & 6 & 2 & 1 & 3 \\
\hline 83 & 3 & Runner & 4 & 1 & 1 & 2 & 118 & 3 & Flower & 6 & 1 & 0 & 1 \\
\hline 84 & 1 & Sailor & 4 & 5 & 2 & 7 & 119 & 2 & Fresh flower & 6 & 21 & 3 & 24 \\
\hline 85 & 3 & Technician & 4 & 1 & 0 & 1 & 120 & 3 & Fruit & 6 & 5 & 3 & 8 \\
\hline 86 & 1 & Criminal & 5 & 3 & 1 & 4 & 121 & 3 & Kid & 6 & 1 & 0 & 1 \\
\hline 87 & 1 & Deadlock & 5 & 2 & 0 & 2 & 122 & 3 & Pet & 6 & 3 & 1 & 4 \\
\hline 88 & 3 & Desert & 5 & 1 & 0 & 1 & 123 & 1 & Question mark & 6 & 1 & 0 & 1 \\
\hline 89 & 2 & Error & 5 & 1 & 0 & 1 & 124 & 3 & Seed & 6 & 1 & 0 & 1 \\
\hline 90 & 1 & Liar & 5 & 1 & 0 & 1 & 125 & 2 & Writer & 8 & 12 & 2 & 14 \\
\hline 91 & 3 & Patient & 5 & 5 & 1 & 6 & 126 & 3 & Creator & 9 & 0 & 1 & 1 \\
\hline 92 & 1 & Pick pocket & 5 & 5 & 2 & 7 & 127 & 1 & Engineer & 9 & 1 & 0 & 1 \\
\hline 93 & 1 & Prisoner & 5 & 2 & 0 & 2 & 128 & 3 & Inventor & 9 & 4 & 0 & 4 \\
\hline 94 & 1 & Rubbish & 5 & 1 & 0 & 1 & 129 & 1 & Gardener & 10 & 2 & 0 & 2 \\
\hline 95 & 1 & Spider & 5 & 1 & 0 & 1 & 130 & 1 & Clothes & 11 & 1 & 0 & 1 \\
\hline 96 & 1 & Spy & 5 & 1 & 0 & 1 & 131 & 1 & Bag & 12 & 1 & 0 & 1 \\
\hline 97 & 2 & Stick & 5 & 3 & 0 & 3 & 132 & 1 & Bank & 12 & 1 & 0 & 1 \\
\hline 98 & 3 & Storm & 5 & 0 & 1 & 1 & 133 & 1 & Basket & 12 & 1 & 0 & 1 \\
\hline 99 & 3 & Sweet & 5 & 2 & 1 & 3 & 134 & 1 & Battery & 12 & 1 & 0 & 1 \\
\hline 100 & 1 & Tear & 5 & 1 & 1 & 2 & 135 & 2 & Blank page & 12 & 0 & 1 & 1 \\
\hline
\end{tabular}




\begin{tabular}{|c|c|c|c|c|c|c|c|c|c|c|c|c|c|}
\hline 101 & 1 & Thief & 5 & 1 & 0 & 1 & 136 & 1 & Board & 12 & 1 & 0 & 1 \\
\hline 102 & 1 & Trouble maker & 5 & 6 & 3 & 9 & 137 & 3 & Boat & 12 & 2 & 1 & 3 \\
\hline 103 & 3 & Turtle & 5 & 1 & 0 & 1 & 138 & 1 & Book & 12 & 1 & 0 & 1 \\
\hline
\end{tabular}

\section{Appendix A (Continued)}

\begin{tabular}{|c|c|c|c|c|c|c|c|c|c|c|c|c|c|}
\hline No & MV & Student Metaphor & CV & ST & TT & Sum & No & MV & Student Metaphor & $\mathbf{C V}$ & ST & TT & Sum \\
\hline 139 & 1 & Bookshelf & 12 & 1 & 0 & 1 & 176 & 2 & Oak & 12 & 0 & 1 & 1 \\
\hline 140 & 1 & Bottle & 12 & 1 & 0 & 1 & 177 & 1 & Page & 12 & 2 & 0 & 2 \\
\hline 141 & 1 & Briefcase & 12 & 1 & 0 & 1 & 178 & 3 & Paper & 12 & 1 & 0 & 1 \\
\hline 142 & 2 & Cabinet & 12 & 0 & 1 & 1 & 179 & 3 & Parrot & 12 & 1 & 1 & 2 \\
\hline 143 & 1 & Calendar & 12 & 1 & 0 & 1 & 180 & 3 & Passenger & 12 & 7 & 3 & 10 \\
\hline 144 & 1 & Camel & 12 & 1 & 0 & 1 & 181 & 3 & Pen & 12 & 0 & 1 & 1 \\
\hline 145 & 1 & Camera & 12 & 1 & 0 & 1 & 182 & 3 & Pencil & 12 & 8 & 1 & 9 \\
\hline 146 & 1 & Candle & 12 & 1 & 0 & 1 & 183 & 3 & Picture & 12 & 1 & 0 & 1 \\
\hline 147 & 3 & Car & 12 & 12 & 2 & 14 & 184 & 3 & Plant & 12 & 2 & 1 & 3 \\
\hline 148 & 3 & Cassette player & 12 & 1 & 1 & 2 & 185 & 2 & Pocket dictionary & 12 & 2 & 4 & 6 \\
\hline 149 & 1 & $\mathrm{CD}$ & 12 & 1 & 0 & 1 & 186 & 1 & Pool & 12 & 1 & 0 & 1 \\
\hline 150 & 1 & Cell phone & 12 & 3 & 0 & 3 & 187 & 1 & Rain & 12 & 1 & 0 & 1 \\
\hline 151 & 1 & Chair & 12 & 1 & 0 & 1 & 188 & 3 & Receiver & 12 & 4 & 0 & 4 \\
\hline 152 & 3 & Clock & 12 & 3 & 1 & 4 & 189 & 1 & Recorder & 12 & 3 & 1 & 4 \\
\hline 153 & 1 & Colors & 12 & 1 & 0 & 1 & 190 & 1 & Room & 12 & 1 & 1 & 2 \\
\hline 154 & 3 & Computer & 12 & 1 & 0 & 1 & 191 & 1 & Skin & 12 & 2 & 0 & 2 \\
\hline 155 & 1 & Cup & 12 & 1 & 0 & 1 & 192 & 3 & Sky & 12 & 1 & 0 & 1 \\
\hline 156 & 1 & Dictionary & 12 & 2 & 1 & 3 & 193 & 1 & Song & 12 & 21 & 3 & 24 \\
\hline 157 & 3 & Dish & 12 & 1 & 1 & 2 & 194 & 1 & Star & 12 & 1 & 0 & 1 \\
\hline 158 & 1 & Envelop & 12 & 2 & 0 & 2 & 195 & 3 & Tape recorder & 12 & 1 & 1 & 2 \\
\hline 159 & 1 & Garden & 12 & 4 & 1 & 5 & 196 & 1 & Theatre & 12 & 1 & 0 & 1 \\
\hline 160 & 3 & Goalkeeper & 12 & 2 & 0 & 2 & 197 & 1 & Tomb & 12 & 0 & 1 & 1 \\
\hline 161 & 1 & Hard worker & 12 & 1 & 0 & 1 & 198 & 3 & Tree & 12 & 0 & 1 & 1 \\
\hline 162 & 1 & House & 12 & 2 & 1 & 3 & 199 & 1 & TV & 12 & 1 & 1 & 2 \\
\hline 163 & 1 & Ink & 12 & 1 & 0 & 1 & 200 & 1 & Vase & 12 & 1 & 0 & 1 \\
\hline 164 & 1 & Kitchen & 12 & 1 & 2 & 3 & 201 & 3 & Wall & 12 & 2 & 1 & 3 \\
\hline 165 & 1 & Library & 12 & 2 & 0 & 2 & 202 & 1 & Whiteboard & 12 & 1 & 1 & 2 \\
\hline 166 & 1 & Light & 12 & 2 & 0 & 2 & 203 & 1 & Wood & 12 & 0 & 1 & 1 \\
\hline 167 & 2 & Lighter & 12 & 2 & 0 & 2 & 204 & 3 & Worker & 12 & 3 & 0 & 3 \\
\hline 168 & 3 & Listener & 12 & 2 & 1 & 3 & 205 & 1 & Air & 13 & 1 & 0 & 1 \\
\hline 169 & 3 & Mirror & 12 & 1 & 0 & 1 & 206 & 1 & Brick & 13 & 1 & 0 & 1 \\
\hline 170 & 1 & Monkey & 12 & 1 & 1 & 2 & 207 & 3 & Brush & 13 & 1 & 1 & 2 \\
\hline 171 & 1 & Moon & 12 & 2 & 0 & 2 & 208 & 3 & Cake & 13 & 1 & 1 & 2 \\
\hline 172 & 1 & Nest & 12 & 1 & 1 & 2 & 209 & 1 & Chalk & 13 & 1 & 0 & 1 \\
\hline 173 & 1 & Newspaper & 12 & 1 & 0 & 1 & 210 & 3 & Chocolate & 13 & 1 & 1 & 2 \\
\hline 174 & 1 & Night & 12 & 1 & 0 & 1 & 211 & 3 & Clay & 13 & 1 & 1 & 2 \\
\hline 175 & 2 & Notebook & 12 & 1 & 0 & 1 & 212 & 1 & Cucumber & 13 & 1 & 0 & 1 \\
\hline
\end{tabular}

\section{Appendix A (Continued)}

\begin{tabular}{|c|c|c|c|c|c|c|c|c|c|c|c|c|c|}
\hline No & MV & Student Metaphor & CV & ST & TT & Sum & No & MV & Student Metaphor & CV & ST & TT & Sum \\
\hline 213 & 3 & Dough & 13 & 1 & 0 & 1 & 228 & 1 & Salad & 13 & 1 & 0 & 1 \\
\hline 214 & 1 & Egg & 13 & 1 & 0 & 1 & 229 & 1 & Salt & 13 & 1 & 0 & 1 \\
\hline 215 & 1 & Gold & 13 & 1 & 1 & 2 & 230 & 1 & Sheet & 13 & 0 & 2 & 2 \\
\hline 216 & 1 & Grape & 13 & 2 & 0 & 2 & 231 & 3 & Shoe & 13 & 2 & 0 & 2 \\
\hline 217 & 2 & Grass & 13 & 1 & 0 & 1 & 232 & 1 & Socks & 13 & 2 & 1 & 3 \\
\hline 218 & 1 & Gum & 13 & 0 & 1 & 1 & 233 & 1 & Tea & 13 & 1 & 1 & 2 \\
\hline 219 & 3 & Gun & 13 & 1 & 0 & 1 & 234 & 3 & Water & 13 & 0 & 1 & 1 \\
\hline 220 & 1 & Honey & 13 & 1 & 0 & 1 & 235 & 1 & Angel & 14 & 5 & 0 & 5 \\
\hline 221 & 1 & Lemon & 13 & 2 & 0 & 2 & 236 & 1 & Bride & 14 & 1 & 0 & 1 \\
\hline 222 & 2 & Meat & 13 & 1 & 0 & 1 & 237 & 3 & Friend & 14 & 0 & 1 & 1 \\
\hline 223 & 1 & Metal & 13 & 1 & 0 & 1 & 238 & 3 & Lion & 15 & 0 & 1 & 1 \\
\hline 224 & 3 & Nail & 13 & 1 & 0 & 1 & 239 & 1 & Manager & 15 & 1 & 0 & 1 \\
\hline 225 & 1 & Pajamas & 13 & 1 & 0 & 1 & & & Total & & 503 & 139 & 641 \\
\hline 226 & 2 & Peach & 13 & 3 & 2 & 5 & & & & & & & \\
\hline 227 & 1 & Pop corn & 13 & 1 & 0 & 1 & & & & & & & \\
\hline
\end{tabular}

\section{APPENDIX B}

245 teacher metaphors produced by students and teachers themselves (MV (Metaphoriser values): 1=students, $2=$ teachers, $3=$ students and teachers; $\mathrm{CV}$ (Category values): $1=$ Absolute compliant, $2=$ Active participant, $3=$ Change agent, $4=$ Cooperative/democratic leader, $5=$ Counselor, $6=$ Curer/repairer, $7=$ Defective individual, $8=$ Entertainer, 9 
$=$ Facilitator/scaffolder, $10=$ Knowledge provider, $11=$ Molder/craftsperson, $12=$ Nurturer/cultivator, $13=$ Superior authoritative figure; ST: Student token or the number of times the metaphor is produced by students; TT: Teacher token or the number of times the metaphor is produced by teachers

\begin{tabular}{|c|c|c|c|c|c|c|c|c|c|c|c|c|c|}
\hline No & MV & Teacher Metaphor & $\mathrm{CV}$ & ST & TT & Sum & No & MV & Teacher Metaphor & $\mathrm{CV}$ & ST & TT & Sum \\
\hline 1 & 3 & Soldier & 1 & 1 & 1 & 2 & 31 & 1 & Nurse & 6 & 3 & 0 & 3 \\
\hline 2 & 1 & Student & 1 & 1 & 0 & 1 & 32 & 1 & Mechanic & 6 & 1 & 0 & 1 \\
\hline 3 & 1 & Swimmer & 2 & 1 & 0 & 1 & 33 & 1 & Pill & 6 & 1 & 0 & 1 \\
\hline 4 & 1 & Autumn & 3 & 1 & 0 & 1 & 34 & 1 & Placebo & 6 & 1 & 0 & 1 \\
\hline 5 & 3 & Dream maker & 3 & 1 & 1 & 2 & 35 & 1 & Tranquilizer & 6 & 1 & 0 & 1 \\
\hline 6 & 1 & Editor & 3 & 1 & 0 & 1 & 36 & 1 & Trash can & 6 & 1 & 0 & 1 \\
\hline 7 & 3 & Guide & 4 & 9 & 2 & 11 & 37 & 1 & Cigarette & 7 & 1 & 0 & 1 \\
\hline 8 & 3 & Leader & 4 & 8 & 3 & 11 & 38 & 1 & Neglect & 7 & 1 & 0 & 1 \\
\hline 9 & 3 & Manager & 4 & 5 & 5 & 10 & 39 & 1 & Stranger & 7 & 1 & 0 & 1 \\
\hline 10 & 3 & Coach & 4 & 4 & 3 & 7 & 40 & 2 & Beggar & 7 & 0 & 1 & 1 \\
\hline 11 & 3 & Director & 4 & 4 & 2 & 6 & 41 & 2 & Turtle & 7 & 0 & 1 & 1 \\
\hline 12 & 3 & Referee & 4 & 2 & 1 & 3 & 42 & 3 & Magician & 8 & 4 & 2 & 6 \\
\hline 13 & 1 & Dish washer & 4 & 1 & 0 & 1 & 43 & 3 & Player & 8 & 4 & 2 & 6 \\
\hline 14 & 3 & Tour guide & 4 & 1 & 4 & 5 & 44 & 1 & Music & 8 & 2 & 0 & 2 \\
\hline 15 & 3 & Father & 5 & 22 & 5 & 27 & 45 & 1 & Beach & 8 & 1 & 0 & 1 \\
\hline 16 & 3 & Mother & 5 & 18 & 5 & 23 & 46 & 1 & Butterfly & 8 & 1 & 0 & 1 \\
\hline 17 & 3 & Friend & 5 & 14 & 6 & 20 & 47 & 1 & Cinema & 8 & 1 & 0 & 1 \\
\hline 18 & 3 & Parent & 5 & 5 & 4 & 9 & 48 & 3 & Clown & 8 & 1 & 2 & 3 \\
\hline 19 & 1 & Sister & 5 & 5 & 0 & 5 & 49 & 1 & Entertainer & 8 & 1 & 0 & 1 \\
\hline 20 & 3 & Counselor & 5 & 4 & 3 & 7 & 50 & 1 & Film & 8 & 1 & 0 & 1 \\
\hline 21 & 3 & Psychologist & 5 & 4 & 2 & 6 & 51 & 1 & Musician & 8 & 1 & 0 & 1 \\
\hline 22 & 1 & Angel & 5 & 3 & 0 & 3 & 52 & 1 & Picnic & 8 & 1 & 0 & 1 \\
\hline 23 & 1 & Brother & 5 & 2 & 0 & 2 & 53 & 1 & Soap opera & 8 & 1 & 0 & 1 \\
\hline 24 & 3 & Mirror & 5 & 2 & 1 & 3 & 54 & 1 & Theatre & 8 & 1 & 0 & 1 \\
\hline 25 & 1 & Grand mother & 5 & 1 & 0 & 1 & 55 & 2 & Circus & 8 & 0 & 1 & 1 \\
\hline 26 & 1 & Wife & 5 & 1 & 0 & 1 & 56 & 3 & Pilot & 9 & 8 & 4 & 12 \\
\hline 27 & 2 & Company & 5 & 0 & 1 & 1 & 57 & 3 & Eraser & 9 & 5 & 1 & 6 \\
\hline 28 & 2 & Consultant & 5 & 0 & 1 & 1 & 58 & 3 & Car & 9 & 4 & 2 & 6 \\
\hline 29 & 2 & Hearer & 5 & 0 & 1 & 1 & 59 & 1 & Chair & 9 & 4 & 0 & 4 \\
\hline 30 & 1 & Doctor & 6 & 5 & 0 & 5 & 60 & 1 & Gun & 9 & 4 & 0 & 4 \\
\hline
\end{tabular}

\section{Appendix B (Continued)}

\begin{tabular}{|c|c|c|c|c|c|c|c|c|c|c|c|c|c|}
\hline No & MV & Teacher Metaphor & CV & ST & TT & Sum & No & MV & Teacher Metaphor & CV & ST & TT & Sum \\
\hline 61 & 1 & Window & 9 & 4 & 0 & 4 & 99 & 1 & Brief case & 9 & 1 & 0 & 1 \\
\hline 62 & 1 & Bed & 9 & 3 & 0 & 3 & 100 & 1 & Cell phone & 9 & 1 & 0 & 1 \\
\hline 63 & 1 & Bus & 9 & 3 & 0 & 3 & 101 & 1 & Classroom & 9 & 1 & 0 & 1 \\
\hline 64 & 1 & Camera & 9 & 3 & 0 & 3 & 102 & 1 & Clock & 9 & 1 & 0 & 1 \\
\hline 65 & 3 & Carpet & 9 & 3 & 1 & 4 & 103 & 1 & Colored pencil & 9 & 1 & 0 & 1 \\
\hline 66 & 1 & Heater & 9 & 3 & 0 & 3 & 104 & 1 & Door & 9 & 1 & 0 & 1 \\
\hline 67 & 1 & Prison & 9 & 3 & 0 & 3 & 105 & 3 & Dress maker & 9 & 1 & 1 & 2 \\
\hline 68 & 1 & Road & 9 & 3 & 0 & 3 & 106 & 3 & Driver & 9 & 1 & 2 & 3 \\
\hline 69 & 1 & Sofa & 9 & 3 & 0 & 3 & 107 & 1 & Elevator & 9 & 1 & 0 & 1 \\
\hline 70 & 1 & Traffic light & 9 & 3 & 0 & 3 & 108 & 1 & Eye & 9 & 1 & 0 & 1 \\
\hline 71 & 1 & Bridge & 9 & 2 & 0 & 2 & 109 & 1 & Gas & 9 & 1 & 0 & 1 \\
\hline 72 & 3 & Comedian & 9 & 2 & 1 & 3 & 110 & 1 & Glove & 9 & 1 & 0 & 1 \\
\hline 73 & 1 & Detective & 9 & 2 & 0 & 2 & 111 & 1 & Handkerchief & 9 & 1 & 0 & 1 \\
\hline 74 & 1 & Feather & 9 & 2 & 0 & 2 & 112 & 1 & Hat & 9 & 1 & 0 & 1 \\
\hline 75 & 1 & Glasses & 9 & 2 & 0 & 2 & 113 & 3 & Horse & 9 & 1 & 1 & 2 \\
\hline 76 & 1 & Gold & 9 & 2 & 0 & 2 & 114 & 1 & Hospital & 9 & 1 & 0 & 1 \\
\hline 77 & 3 & Machine & 9 & 2 & 2 & 4 & 115 & 1 & Metal & 9 & 1 & 0 & 1 \\
\hline 78 & 1 & Marker & 9 & 2 & 0 & 2 & 116 & 1 & Money & 9 & 1 & 0 & 1 \\
\hline 79 & 1 & Motorcycle & 9 & 2 & 0 & 2 & 117 & 1 & Moon & 9 & 1 & 0 & 1 \\
\hline 80 & 3 & Pillow & 9 & 2 & 1 & 3 & 118 & 1 & \begin{tabular}{|l|} 
Platform \\
\end{tabular} & 9 & 1 & 0 & 1 \\
\hline 81 & 1 & Spoon & 9 & 2 & 0 & 2 & 119 & 1 & Rope & 9 & 1 & 0 & 1 \\
\hline 82 & 1 & Umbrella & 9 & 2 & 0 & 2 & 120 & 1 & Rug & 9 & 1 & 0 & 1 \\
\hline 83 & 1 & Vase & 9 & 2 & 0 & 2 & 121 & 1 & Saw & 9 & 1 & 0 & 1 \\
\hline 84 & 1 & Wall & 9 & 2 & 0 & 2 & 122 & 1 & Screw driver & 9 & 1 & 0 & 1 \\
\hline 85 & 1 & Washing machine & 9 & 2 & 0 & 2 & 123 & 1 & Seller & 9 & 1 & 0 & 1 \\
\hline 86 & 1 & Whiteboard & 9 & 2 & 0 & 2 & 124 & 1 & Shoe & 9 & 1 & 0 & 1 \\
\hline 87 & 1 & Worker & 9 & 2 & 0 & 2 & 125 & 1 & Slippers & 9 & 1 & 0 & 1 \\
\hline 88 & 1 & Airport & 9 & 1 & 0 & 1 & 126 & 1 & Soft ware & 9 & 1 & 0 & 1 \\
\hline 89 & 1 & Anorak & 9 & 1 & 0 & 1 & 127 & 1 & Stove & 9 & 1 & 0 & 1 \\
\hline 90 & 1 & Appetizer & 9 & 1 & 0 & 1 & 128 & 1 & Sweet & 9 & 1 & 0 & 1 \\
\hline 91 & 1 & Apron & 9 & 1 & 0 & 1 & 129 & 1 & \begin{tabular}{|l|} 
Ticket \\
\end{tabular} & 9 & 1 & 0 & 1 \\
\hline
\end{tabular}




\begin{tabular}{|c|c|c|c|c|c|c|c|c|c|c|c|c|c|}
\hline 92 & 3 & Battery & 9 & 1 & 1 & 2 & 130 & 1 & Tie & 9 & 1 & 0 & 1 \\
\hline 93 & 1 & Belt & 9 & 1 & 0 & 1 & 131 & 1 & Tier & 9 & 1 & 0 & 1 \\
\hline 94 & 1 & Blanket & 9 & 1 & 0 & 1 & 132 & 1 & Tire & 9 & 1 & 0 & 1 \\
\hline 95 & 1 & Blouse & 9 & 1 & 0 & 1 & 133 & 3 & Tutor & 9 & 1 & 1 & 2 \\
\hline 96 & 1 & Board & 9 & 1 & 0 & 1 & 134 & 1 & Vest & 9 & 1 & 0 & 1 \\
\hline 97 & 1 & Boat & 9 & 1 & 0 & 1 & 135 & 1 & Waiter & 9 & 1 & 0 & 1 \\
\hline 98 & 1 & Boulevard & 9 & 1 & 0 & 1 & 136 & 2 & Cloth & 9 & 0 & 1 & 1 \\
\hline
\end{tabular}

\section{Appendix B (Continued)}

\begin{tabular}{|c|c|c|c|c|c|c|c|c|c|c|c|c|c|}
\hline No & MV & Teacher Metaphor & $\mathrm{CV}$ & ST & TT & Sum & No & MV & Teacher Metaphor & $\mathrm{CV}$ & ST & TT & Sum \\
\hline 137 & 2 & Fuel & 9 & 0 & 1 & 1 & 174 & 1 & Spring & 10 & 1 & 0 & 1 \\
\hline 138 & 2 & Phone & 9 & 0 & 1 & 1 & 175 & 1 & Stadium & 10 & 1 & 0 & 1 \\
\hline 139 & 2 & Scissors & 9 & 0 & 1 & 1 & 176 & 1 & Teacher & 10 & 1 & 0 & 1 \\
\hline 140 & 2 & Server & 9 & 0 & 1 & 1 & 177 & 1 & Tower & 10 & 1 & 0 & 1 \\
\hline 141 & 3 & Candle & 10 & 20 & 3 & 23 & 178 & 1 & Village & 10 & 1 & 0 & 1 \\
\hline 142 & 3 & Computer & 10 & 7 & 2 & 9 & 179 & 1 & Waterfall & 10 & 1 & 0 & 1 \\
\hline 143 & 1 & Tree & 10 & 7 & 0 & 7 & 180 & 1 & Wave & 10 & 1 & 0 & 1 \\
\hline 144 & 1 & Light & 10 & 6 & 0 & 6 & 181 & 3 & Writer & 10 & 1 & 1 & 2 \\
\hline 145 & 1 & Mountain & 10 & 6 & 0 & 6 & 182 & 2 & Container & 10 & 0 & 1 & 1 \\
\hline 146 & 3 & Sun & 10 & 6 & 1 & 7 & 183 & 3 & Researcher & 11 & 6 & 3 & 9 \\
\hline 147 & 1 & TV & 10 & 6 & 0 & 6 & 184 & 1 & Barber & 11 & 4 & 0 & 4 \\
\hline 148 & 1 & Flower & 10 & 5 & 0 & 5 & 185 & 3 & Conductor & 11 & 2 & 3 & 5 \\
\hline 149 & 1 & Rain & 10 & 4 & 0 & 4 & 186 & 3 & Cook & 11 & 2 & 2 & 4 \\
\hline 150 & 1 & House & 10 & 3 & 0 & 3 & 187 & 1 & Baker & 11 & 1 & 0 & 1 \\
\hline 151 & 1 & Ink & 10 & 3 & 0 & 3 & 188 & 1 & Businessman & 11 & 1 & 0 & 1 \\
\hline 152 & 1 & Water & 10 & 3 & 0 & 3 & 189 & 1 & Chemist & 11 & 1 & 0 & 1 \\
\hline 153 & 1 & Bag & 10 & 2 & 0 & 2 & 190 & 1 & Engineer & 11 & 1 & 0 & 1 \\
\hline 154 & 3 & Book & 10 & 2 & 1 & 3 & 191 & 1 & Groom & 11 & 1 & 0 & 1 \\
\hline 155 & 1 & Jungle & 10 & 2 & 0 & 2 & 192 & 1 & Hammer & 11 & 1 & 0 & 1 \\
\hline 156 & 3 & Library & 10 & 2 & 1 & 3 & 193 & 3 & Painter & 11 & 1 & 2 & 3 \\
\hline 157 & 1 & Museum & 10 & 2 & 0 & 2 & 194 & 1 & Undertaker & 11 & 1 & 0 & 1 \\
\hline 158 & 1 & Note book & 10 & 2 & 0 & 2 & 195 & 2 & Artist & 11 & 0 & 2 & 2 \\
\hline 159 & 1 & Parrot & 10 & 2 & 0 & 2 & 196 & 2 & Cutter & 11 & 0 & 2 & 2 \\
\hline 160 & 1 & Pen & 10 & 2 & 0 & 2 & 197 & 2 & Photographer & 11 & 0 & 1 & 1 \\
\hline 161 & 3 & Radio & 10 & 2 & 2 & 4 & 198 & 2 & Programmer & 11 & 0 & 1 & 1 \\
\hline 162 & 1 & Treasure & 10 & 2 & 0 & 2 & 199 & 2 & Sharpener & 11 & 0 & 1 & 1 \\
\hline 163 & 1 & Wallet & 10 & 2 & 0 & 2 & 200 & 3 & Sea & 12 & 8 & 4 & 12 \\
\hline 164 & 3 & Bookcase & 10 & 1 & 1 & 2 & 201 & 3 & Gardener & 12 & 6 & 4 & 10 \\
\hline 165 & 1 & Dam & 10 & 1 & 0 & 1 & 202 & 1 & Cloud & 12 & 5 & 0 & 5 \\
\hline 166 & 1 & Encyclopedia & 10 & 1 & 0 & 1 & 203 & 3 & Sky & 12 & 3 & 1 & 4 \\
\hline 167 & 1 & Fire & 10 & 1 & 0 & 1 & 204 & 1 & Blood & 12 & 2 & 0 & 2 \\
\hline 168 & 1 & Flood & 10 & 1 & 0 & 1 & 205 & 1 & Blossom & 12 & 2 & 0 & 2 \\
\hline 169 & 1 & Magazine & 10 & 1 & 0 & 1 & 206 & 1 & Food & 12 & 2 & 0 & 2 \\
\hline 170 & 1 & Mansion & 10 & 1 & 0 & 1 & 207 & 1 & Pizza & 12 & 2 & 0 & 2 \\
\hline 171 & 3 & Owl & 10 & 1 & 2 & 3 & 208 & 1 & Apple & 12 & 1 & 0 & 1 \\
\hline 172 & 1 & Picture & 10 & 1 & 0 & 1 & 209 & 1 & Bread & 12 & 1 & 0 & 1 \\
\hline 173 & 1 & Pool & 10 & 1 & 0 & 1 & 210 & 1 & Cream & 12 & 1 & 0 & 1 \\
\hline
\end{tabular}

\section{Appendix B (Continued)}

\begin{tabular}{|c|c|c|c|c|c|c|c|c|c|c|c|c|c|}
\hline No & MV & Teacher Metaphor & CV & ST & TT & Sum & No & MV & Teacher Metaphor & $\mathbf{C V}$ & ST & TT & Sum \\
\hline 211 & 1 & Earth & 12 & 1 & 0 & 1 & 229 & 2 & Honey & 12 & 0 & 1 & 1 \\
\hline 212 & 3 & Farm & 12 & 1 & 1 & 2 & 230 & 2 & Ice cream & 12 & 0 & 1 & 1 \\
\hline 213 & 1 & Farmer & 12 & 1 & 0 & 1 & 231 & 3 & Boss & 13 & 7 & 1 & 8 \\
\hline 214 & 1 & Field & 12 & 1 & 0 & 1 & 232 & 1 & Police & 13 & 4 & 0 & 4 \\
\hline 215 & 1 & Garden & 12 & 1 & 0 & 1 & 233 & 1 & Professor & 13 & 2 & 0 & 2 \\
\hline 216 & 1 & Kitchen & 12 & 1 & 0 & 1 & 234 & 3 & Ruler & 13 & 2 & 1 & 3 \\
\hline 217 & 1 & Laptop & 12 & 1 & 0 & 1 & 235 & 3 & Babysitter & 13 & 1 & 1 & 2 \\
\hline 218 & 3 & Ocean & 12 & 11 & 2 & 3 & 236 & 1 & Commander & 13 & 1 & 0 & 1 \\
\hline 219 & 1 & Pepper & 12 & 1 & 0 & 1 & 237 & 3 & Creator & 13 & 1 & 1 & 2 \\
\hline 220 & 1 & Queen & 12 & 1 & 0 & 1 & 238 & 1 & Interviewer & 13 & 1 & 0 & 1 \\
\hline 221 & 1 & Restaurant & 12 & \begin{tabular}{|l|}
1 \\
\end{tabular} & 0 & 1 & 239 & 1 & Lion & 13 & 1 & 0 & 1 \\
\hline 222 & 1 & River & 12 & 1 & 0 & 1 & 240 & 1 & Police officer & 13 & 1 & 0 & 1 \\
\hline 223 & 1 & Spice & 12 & 1 & 0 & 1 & 241 & 1 & President & 13 & 1 & 0 & 1 \\
\hline 224 & 1 & Sponsor & 12 & 1 & 0 & 1 & 242 & 1 & Remote control & 13 & 1 & 0 & 1 \\
\hline 225 & 2 & Baby & 12 & 0 & 1 & 1 & 243 & 1 & Rod & 13 & 1 & 0 & 1 \\
\hline 226 & 2 & Cake & 12 & 0 & 2 & 2 & 244 & 2 & Big brother & 13 & 0 & 1 & 1 \\
\hline 227 & 2 & Chocolate & 12 & 0 & 1 & 1 & 245 & 2 & $\mathrm{Ox}$ & 13 & 0 & 1 & 1 \\
\hline 228 & 2 & Grape & 12 & 0 & 1 & 1 & & & Total & & 504 & 140 & 644 \\
\hline
\end{tabular}




\section{REFERENCES}

[1] Burke, K. (1945). A grammar of motives. New York: Prentice Hall.

[2] Cameron, L. (1999). 1 Operationalizing 'metaphor' for applied linguistic research. In L. Cameron, \& G. Low (Eds.), Researching and applying metaphor (pp. 3-28). Cambridge: CUP.

[3] Khodadady, E. (1997). Schemata theory and multiple choice item tests measuring reading comprehension. Unpublished PhD thesis, the University of Western Australia.

[4] Khodadady, E. (1999). Multiple-choice items in testing: Practice and theory. Tehran: Rahnama.

[5] Khodadady, E., \& Elahi, M. (2012). The Effect of Schema-Vs-Translation-Based Instruction on Persian Medical Students' Learning of General English. English Language Teaching, 5 (1), xx-xxx.

[6] Khodadady, E., \& Herriman, M. (2000). Schemata theory and selected response item tests: from theory to practice. In A. J. Kunnan (Ed.), Fairness and validation on language assessment (pp. 201-222). Cambridge: CUP.

[7] Khodadady, E., Pishghadam, R., \& Fakhar, M. (2010). The relationship among reading comprehension ability, grammar and vocabulary knowledge: An experimental and schema-based approach. Iranian EFL Journal, 6(2), 7-49.

[8] Khodadady, E., Shirmohammadi, S., \& Talebi, F. (2011). Brainstorming and its effect on critical thinking and speaking skills. Iranian EFL Journal, 7(1), 51-66.

[9] Lakoff, G. \& Johnson, M. (2005). Metaforlar Hayat, Anlam ve Dil. (Çev: G. Y. Demir). Istanbul: Paradigma Yayınları.

[10] Miles, M. B., \& Huberman, A. M. (1994). Qualitative data analysis (2nd ed.), Thousand Oaks, CA: Sage.

[11] Perrine, L. (1971). Four forms of metaphor. College English, 33, 125-138.

[12] Phillips, D. C. (1996). Philosophical perspectives. In D. C. Berliner, \& R. C. Calfee (Eds.), Handbook of educational psychology (pp. 1019-1105). New York: Simon \& Schuster Macmillan.

[13] Richards, I. A. (1936/1979). The philosophy of Rhetoric. Oxford: OUP.

[14] Richards, J. C. \& Rodgers, T. (2001). Approaches and methods in language teaching: A description and analysis ( $2^{\text {nd }}$ ed.). Cambridge: CUP.

[15] Saban, A., Kocbeker, B. N., \& Saban, A. (2007). Prospective teachers' conceptions of teaching and learning revealed through metaphor analysis. Learning and Instruction, 17, 123-139.

[16] Yazic1, N. (2010). Metaphors on "Literature" by teachers-to-be graduates of Turkish language and literature departments. Procedia Social and Behavioral Sciences, 2, 5339-5343. doi:10.1016/j.sbspro.2010.03.870.

[17] Yob, I. M. (2003). Thinking constructively with metaphors. Studies in Philosophy and Education, 22, 127-138.

Ebrahim Khodadady is an academic member of English Language and Literature Department at Ferdowsi University of Mashhad, Iran. His main research interests are Testing, Language Learning and Teaching.

Mostafa Morady Moghaddam is currently a PhD student of Teaching English as a Foreign Language (TEFL) at University of Tabriz, Iran.

Hoda Kanan Azar is an MA student of Teaching English as a Foreign Language at Ferdowsi University of Mashhad, Iran, International Branch 